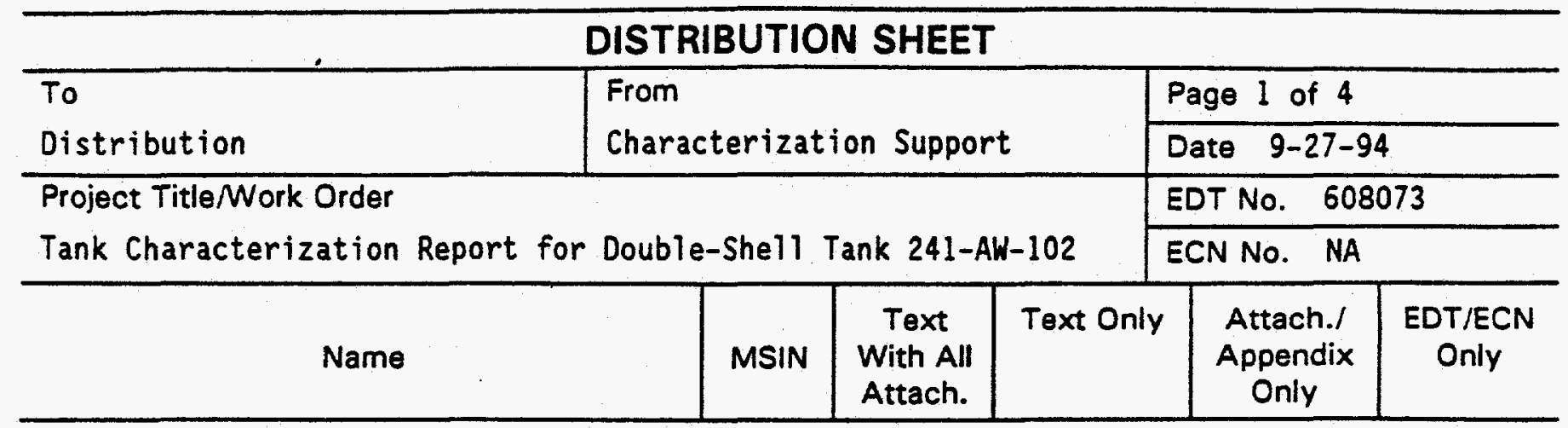

OFFSITE

Sandia National Laboratory

P.0. Box 5800

MS-0744, Dept. 6404

Albuquerque, NM 87815

D. Powers

Nuclear Consulting Services Inc.

P.0. Box 29151

Columbus, $\mathrm{OH}$ 43229-01051

J. L. Kovach

$x$

Chemical Reaction Sub-TAP

202 Northridge Court

Lindsborg, KS 67456

B. C. Hudson

$x$

Tank Characterization Panel

Senior Technical Consultant

Contech

6301 Indian School Road NE, Suite 614

Albuquerque, NM 87110

J. Arvizu

$x$

U.S. Department of Energy - Headquarters

Office of Environmental Restoration and Waste Management EM-563

12800 Middlebrook Road

Germantown, MD 20874

K. T. Lang

J. A. Poppitti

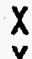

SAIC

2030 Centry Boulevard

Suite 200-B

Germantown, MD 20874

H. Sutter

$x$ 


\section{DISCLAIMER}

This report was prepared as an account of work sponsored by an agency of the United States Government. Neither the United States Government nor any agency thereof, nor any of their employees, make any warranty, express or implied, or assumes any legal liability or responsibility for the accuracy, completeness, or usefulness of any information, apparatus, product, or process disclosed, or represents that its use would not infringe privately owned rights. Reference herein to any specific commercial product, process, or service by trade name, trademark, manufacturer, or otherwise does not necessarily constitute or imply its endorsement, recommendation, or favoring by the United States Government or any agency thereof. The views and opinions of authors expressed herein do not necessarily state or reflect those of the United States Government or any agency thereof. 


\section{DISCLAIMER}

\section{Portions of this document may be illegible in electronic image products. Images are produced from the best available original document.}


Los Alamos Laboratory

CST-14 MS-J586

P.0. Box 1663

Los Alamos, NM 87545

S. F. Agnew (6)

Los Alamos Technical Associates

750 Swift Blvd., Suite 4

Richland, WA 99352

A. T. DiCenso

$x$

Ogden Environmental

101 East Wellsian Way

Richland, WA 99352

R. J. Anema

$X$

$\mathrm{CH} 2 \mathrm{MH} H \mathrm{HI}$

P.0. BoX 91500

Bellevue, WA 98009-2050

M. McAfee

$x$

Tank Advisory Panel

102 Windham Road

Oak Ridge, TN 37830

D. O. Campbell

$x$

\section{ONSITE}

Department of Ecology

A. B. Stone (4)

N1-05

$x$

Department of Energy - Richland Operations

J. M. Clark

$57-54 \quad x$

R. E. Gerton

$57-54$

J. R. Noble-Dial

$57-54$

EDT- 608073 PS 2 of 4

\section{ICF-Kaiser Hanford Company}

C. H. Brevick

L. A. Gaddis

R. B. Johnson

W. W. Pickett

G7-56

GT-57

G7-56

G7-57

$x$
$x$
$x$

Pacific Northwest Laboratories

W. J. Apley

R. M. Bean

S. F. Bobrowski

P. G. Eller

E. J. Eschbach

$57-71$

P8-08

K $7-28$

$B 1-40$

K7-15

$x$
$x$
$x$
$x$

A-6000-135 (01/93) WEF067 

J. G. Hill
K7-97
L. K. Holton
P7-43
$\mathrm{K} 1-78$
B. M. Johnson
G. J. Lumetta
P7 -25
B. D. McVeety
K6-63
I. C. McVeety
KT-22
P. J. Mellinger
P7-22
A. F. Noonan
L. R. Pederson
B1-40
K2-44

$x$
$x$
$x$
$x$
$x$
$x$
$x$
$x$
$x$

\section{Westinghouse Hanford Company}

H. Babad

D. A. Barnes

A. L. Boldt

G. L. Borsheim

D. R. Bratzel

T. M. Brown

T. H. Bushaw

M. P. Campbell

R. J. Cash

G. M. Christensen

W. L. Cowley

M. L. Deffenbaugh

C. DeFigh-Price

R. A. Dodd

G. L. Dunford

S. J. Eberlein

D. B. Engelman

K. 0. Fein

J. S. Garfield

K. D. Gibson

C. E. Golberg

J. M. Grigsby

R. D. Gustayson

C. S. Haller

H. W. Heacock

D. L. Herting

B. A. Higley

G. Jansen

G. D. Johnson

K. K. Kawabata

N. W. Kirch

M. J. Kupfer

G. A. Meyer

W. C. Miller

W. C. Mills

C. T. Narquis

R. H. Palmer

M. A. Payne

S. H. Rifaey

R. R. Rios

D. A. Reynolds

P. Sathyanarayana (2)

F. A. Schmittroth

J. S. Schofield
57-30

R1-51

H5- 49

H5-27

$57-31$

R2-12

T6-30

R2-86

S7-15

H4-21

H4 -61

R2-06

S7-30

R2-70

R2-50

S7-31

R1-49

H4-63

H5-49

H4-6I

H5-49

$\mathrm{H} 4-62$

R1-51

R2-12

$57-81$

T6-09

H5-27

H6-33

\$7-15

T6-50

R2-11

H5-49

S4-54

S4-55

S4-58

T6-50

R2-58

S7-14

S2-45

R1-80

R2-11

R2-12

HO-35

R1-67 
Distribution

5. Proj./Prog./Dept./Div.:

WM/Characterization

8. Originator Remarks:

Tank Characterization Report for Double-Shell Tank 241-AW102. This report contributes to the fulfillment of TPA Milestone M-44-05

11. Receiver Remarks:
2. To: (Receiving Organization)

\begin{tabular}{|l|l|}
\hline $\begin{array}{l}\text { 3. From: coriginating organization) } \\
\text { Characterization Support }\end{array}$ & 4. Related EDT No.: \\
\hline $\begin{array}{l}\text { 6. Cog. Engr.: } \\
\text { B. C. Simpson }\end{array}$ & 7. Purchase Order No.: \\
\hline
\end{tabular}

9. Equip./Component No.: NA

10. System/Bldg./Facility: Tank Farms

12. Major Assm. Dwg. No.: NA

13. Permit/Permit Application No.: NA

14. Required Response Date: Sept. 13, 1994

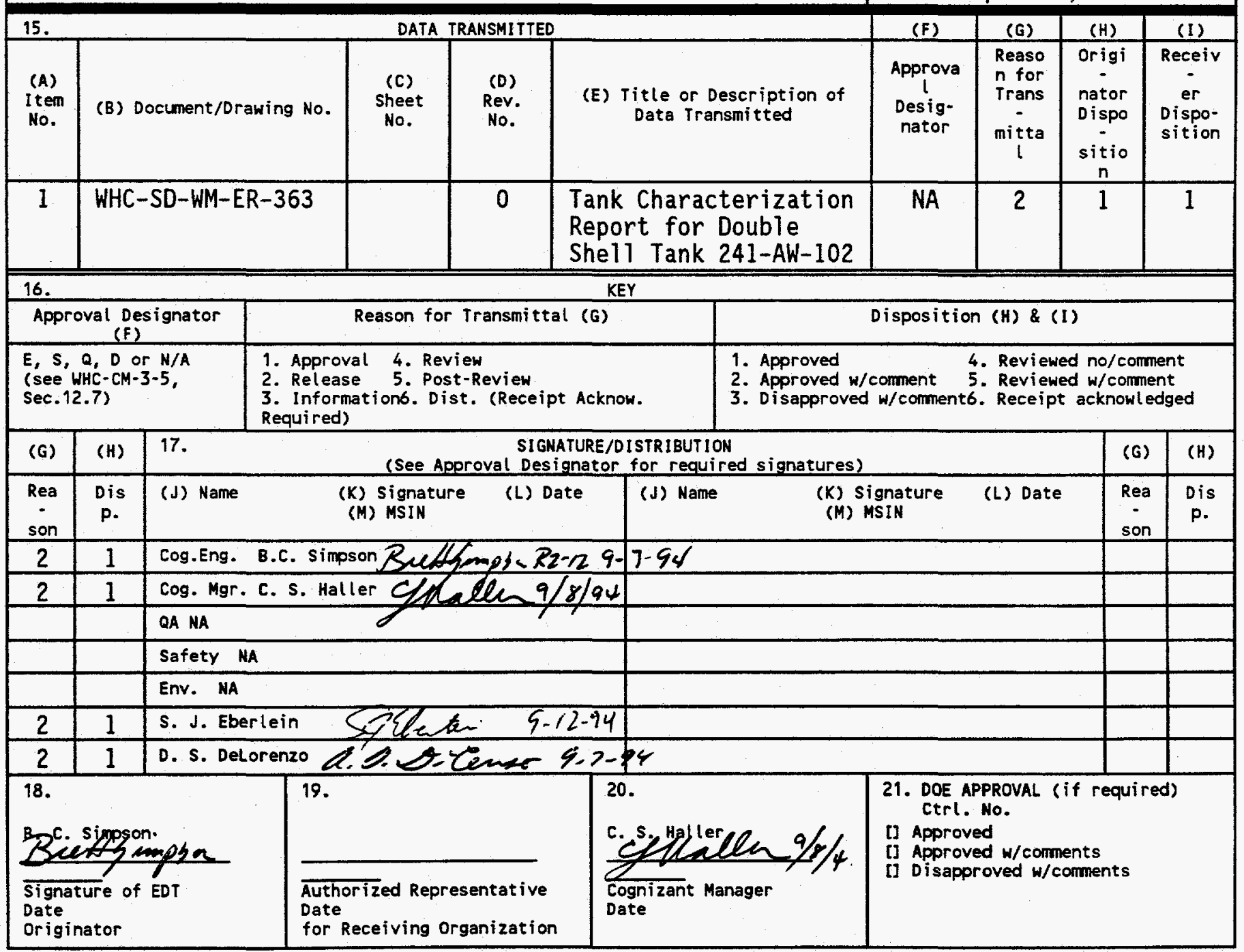

BD-7400-172-2(04/94) GEF097 


\section{RELEASE AUTHORIZATION}

\begin{tabular}{|ll}
\hline Document Number: & WHC-SD-WM-ER-363, REV.0 \\
\hline Document Title: & $\begin{array}{l}\text { Tank Characterization Report for Double-She11 Tank } \\
241-\text { AW-102 }\end{array}$
\end{tabular}

Release Date:

September 28, 1994

This document was reviewed following the procedures described in WHC-CM-3-4 and is:

APPROVED FOR PUBLIC RELEASE

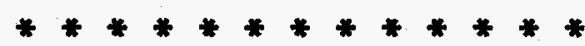

WHC Information Release Administration Specialist:

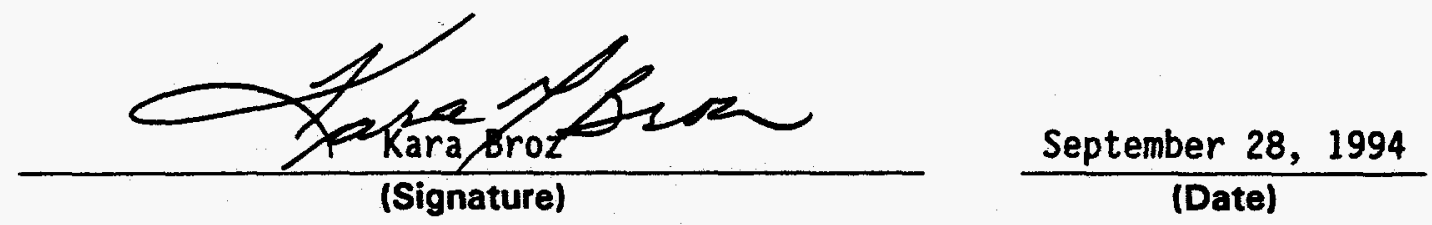




\section{SUPPORTING DOCUMENT}

1. Total Pages 25

\begin{tabular}{|c|c|c|}
\hline $\begin{array}{l}\text { 2. Title } \\
\text { Tank Characterization Report for Double-She } 11 \text { Tank } \\
\text { 241-AW-102 }\end{array}$ & $\begin{array}{l}\text { 3. Number } \\
\text { WHC-SD-WM-ER-363 }\end{array}$ & $\begin{array}{c}\text { 4. Rev No. } \\
0\end{array}$ \\
\hline $\begin{array}{l}\text { 5. Key words } \\
\text { Waste Characterization; Double-Shel1 Tank; AW-102; } \\
\text { Tank Characterization Report; Evaporator Feed } \\
\text { Tank; Active Process Tank; 242-A Evaporator; TPA } \\
\text { Milestone M-44 }\end{array}$ & $\begin{array}{l}\text { 6. Author } \\
\text { Name: A.T. DiCens } \\
\text { signature } \\
\text { Organization/Charge cod }\end{array}$ & 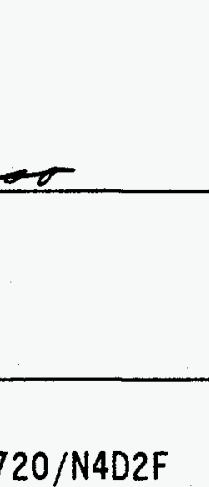 \\
\hline \multicolumn{3}{|c|}{$\begin{array}{l}\text { 7. Abstract } \\
\text { This document provides the essential characterization data for Double-She } 11 \text { Tank AW- } \\
102\end{array}$} \\
\hline 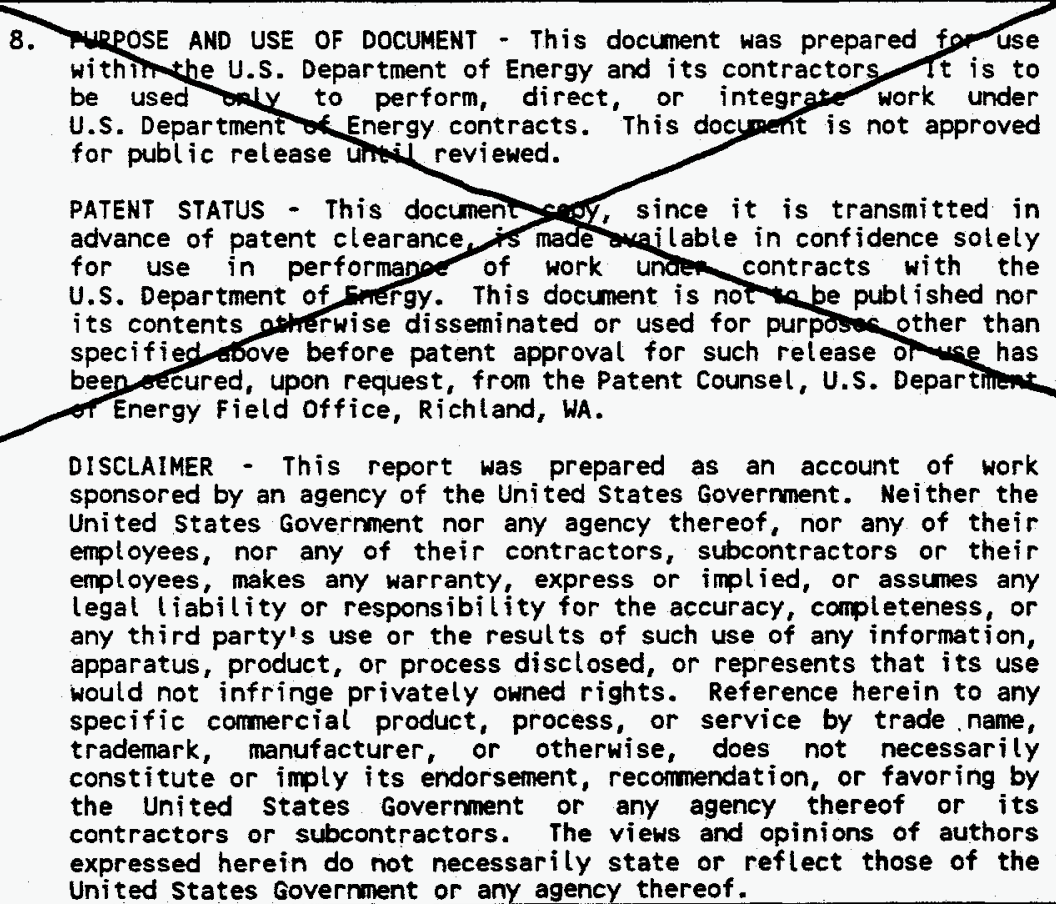 & \multirow[t]{2}{*}{$\begin{array}{r}\text { OFFICIALFE } \\
\text { BYWHC } \\
\text { DATE SEF } \\
\text { STA } 4\end{array}$} & $\frac{(13)}{1994}$ \\
\hline & & \\
\hline
\end{tabular}




\title{
Tank Characterization Report for Double-Shell Tank 241-AW-102
}

\author{
A. T. DiCenso \\ L. C. Amato \\ J. D. Franklin \\ G. L. Nuttall \\ T. T. Tran \\ Los Alamos Technical Associates, Incorporated
}

B. C. Simpson

Westinghouse Hanford Company

Date Published

September 1994

Prepared for Westinghouse Hanford Company by Los Alamos Technical Associates 8633 Gage Blvd.

Kennewick, WA 99336 


\section{EXECUTIVE SUMMARY}

Double-Shell Tank 241-AW-102 is an underground storage tank containing radioactive waste, located on the Department of Energy's Hanford Site. Sampling and characterization of the waste in Tank 241-AW-102 contribute toward the fulfillment of Milestone M-44-05 of the Hanford Federal Facility Agreement and Consent Order (Ecology, EPA, and DOE, 1993). Characterization will also provide support for Tank Farm Operations, safety programs, and design of retrieval, pretreatment, and disposal systems.

Tank 241-AW-102, located in the 200 East Area AW Tank Farm, was constructed and went into service in 1980 . The tank is presently used as the feed tank for Evaporator 242-A, and thus received extensive use in the recently completed Evaporator 242-A Campaign 94-1. Although that campaign is finished, Tank 241-AW-102 is in continual use. Any surface level or temperature data reported for Tank 241-AW-102 were current as of June 20, 1994, but may have since changed. The final disposal of the waste in Tank 241-AW-102 will be as high- and lowlevel glass fractions following processing through the 242-A Evaporator-crystallizer

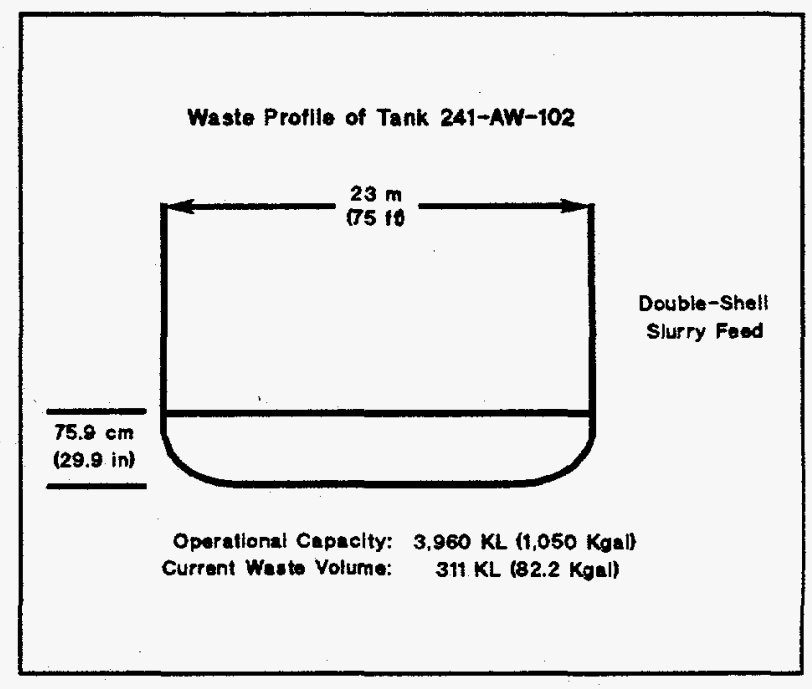
and pretreatment to partition the fractions.

The tank has an operational capacity of $3,960,000 \mathrm{~L}(1,050,000$ gallons $)$, and as of June 20 , 1994 , contained $311,000 \mathrm{~L}(82,200$ gallons $)$ of double-shell slurry feed. The tank is classified as a non-Watch List tank and is considered to be a sound or non-leaking tank. There are no Unreviewed Safety Questions associated with Tank 241-AW-102 at this time.

The latest sampling and characterization activity (O'Rourke, 1994) indicated that the most prevalent analytes include aluminum, sodium, fluoride, nitrate, nitrite, hydroxide, phosphate, sulfate, and carbonate. The major radionuclide constituent is ${ }^{137} \mathrm{Cs}$. The calculated pH of 13.1 is above the Resource Conservation and Recovery Act (EPA, 1990) established limits for corrosivity. Comparisons to established limits of concern for selected analytes can be made by referring to the Tank Characterization Reference Guide (De Lorenzo et al., 1994).

Estimated contents of the tank have been compared to the dangerous waste codes in the Washington Dangerous Waste Regulations (Ecology, 1991). This assessment was conducted by comparing tank contents against dangerous waste characteristics (" $D$ " waste codes) and against state waste codes. It did not include checking tank contents against " $U$ ", "P", "F", or "K" waste codes since application of these codes is dependent on the source of the waste and not on particular constituent concentrations. The results indicate that the waste in this tank is adequately described in the Dangerous Waste Permit Application for the Double-Shell Tank System; this permit is discussed in the Tank Characterization Reference Guide (De Lorenzo et al., 1994). 
WHC-SD-WM-ER-363 REV O

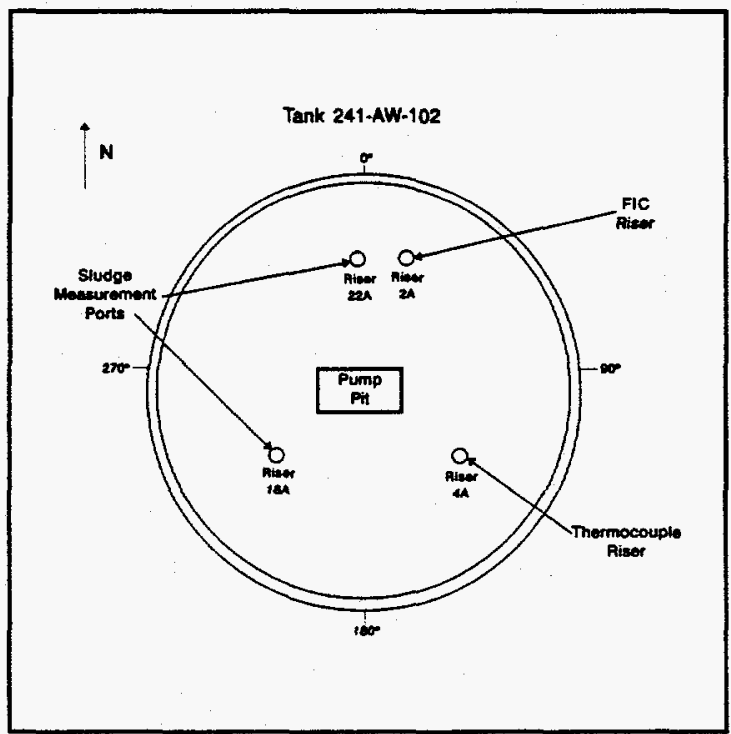

\begin{tabular}{|c|c|}
\hline \multicolumn{2}{|c|}{ TANK 241-AW-102 } \\
\hline \multicolumn{2}{|c|}{ Tank Description } \\
\hline Type: & Double-Shell \\
\hline Constructed: & 1980 \\
\hline In-Service: & 1980 \\
\hline Diameter: & $\begin{array}{r}23 \mathrm{~m} \\
(75 \text { feet })\end{array}$ \\
\hline Usable Depth: & $\begin{array}{r}11 \mathrm{~m} \\
\text { (35 feet) }\end{array}$ \\
\hline Operating Capacity: & $\begin{array}{r}3,960,000 \mathrm{~L} \\
(1,050,000 \text { gallons })\end{array}$ \\
\hline Bottom Shape: & Flat \\
\hline Hanford Coordinates: & $\begin{array}{l}40,704^{\circ} \text { North } \\
47,645^{\circ} \text { West }\end{array}$ \\
\hline Ventilation: & Operating Exhauster \\
\hline Airlift Circulators: & Two \\
\hline \multicolumn{2}{|c|}{ Tank Status (as of June 20. 1994) } \\
\hline Contents: & $\begin{array}{r}\text { Double-Shell Slurry } \\
\text { Feed }\end{array}$ \\
\hline Total Waste: & $\begin{array}{r}311,000 \mathrm{~L} \\
(82,200 \text { gallons })\end{array}$ \\
\hline Manual Tape Surface Level: & $\begin{array}{r}73.7 \mathrm{~cm} \\
(29.0 \text { inches })\end{array}$ \\
\hline FIC Surface Level: & $\begin{array}{r}75.9 \mathrm{~cm} \\
(29.9 \text { inches) }\end{array}$ \\
\hline Temperature: & $\begin{array}{r}33^{\circ} \mathrm{C} \\
\left(91^{\circ} \mathrm{F}\right)\end{array}$ \\
\hline Integrity Category: & Sound \\
\hline
\end{tabular}




\begin{tabular}{|c|c|c|}
\hline \multicolumn{3}{|c|}{$\begin{array}{l}\text { Double-Shell Tank } 241-A W-102 \text { Concentrations and Inventories } \\
\text { for Critical List Analytes (based on historical data from } \\
1993 \text { supernate sampling \& June } 1994 \text { Volume Update) }\end{array}$} \\
\hline Waste Volume & \multicolumn{2}{|c|}{$311,000 \mathrm{~L}(82,200$ gallons $)$} \\
\hline $\begin{array}{l}\text { Chemical } \\
\text { Constituents }\end{array}$ & $\begin{array}{l}\text { Average Liquid } \\
\text { Concentration }\end{array}$ & $\begin{array}{l}\text { Liquid Bulk } \\
\text { Inventory }\end{array}$ \\
\hline Metals & (wt\%) & $(\mathrm{kg})$ \\
\hline Al (Aluminum) & 0.03 & 108 \\
\hline $\mathrm{Na}$ (Sodium) & 1.19 & 3,700 \\
\hline Anions & $(w t \%)$ & $(\mathrm{kg})$ \\
\hline$F^{*}$ (Fluoride) & 0.28 & 886 \\
\hline $\mathrm{OH}^{-}$(Hydroxide) & 0.20 & 634 \\
\hline $\mathrm{NO}_{3} \cdot$ (Nitrate) & 1.02 & 3,170 \\
\hline $\mathrm{NO}_{2}^{-}$(Nitrite) & 0.18 & 566 \\
\hline $\mathrm{SO}_{4}^{2-}$ (Sulfate) & 0.17 & 541 \\
\hline Radionuclide & $(\mu \mathrm{Ci} / \mathrm{mL})$ & (Ci) \\
\hline${ }^{137} \mathrm{Cs}$ & 15.3 & 4,760 \\
\hline
\end{tabular}

The inventory estimates presented here are for information purposes only. They were calculated based on the assumptions that the historical analyte concentrations and waste volumes remained constant. Tank 241-AW-102 is currently in-service and is involved in the various ongoing waste management operations at the Hanford Site. Real-time tank inventories can be obtained from Tank Farm Operations. The Tank Characterization Reports for tanks still receiving waste will be revised as new information becomes available, on a quarterly basis, if necessary. However, due to the inherent delay in the revision and issuance of the document, the most current and authoritative data will be with Tank Farm Operations personnel. 


\section{CONTENTS}

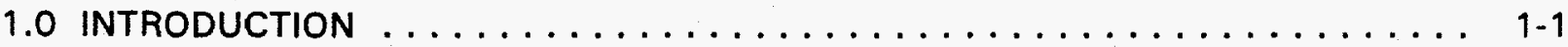

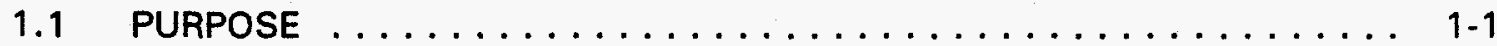

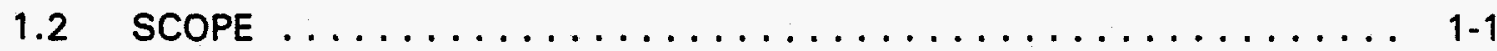

1.3 ASSUMPTIONS $\ldots \ldots \ldots \ldots \ldots \ldots \ldots \ldots \ldots \ldots \ldots \ldots \ldots \ldots \ldots \ldots \ldots \ldots, 1-1$

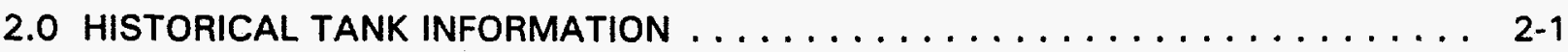

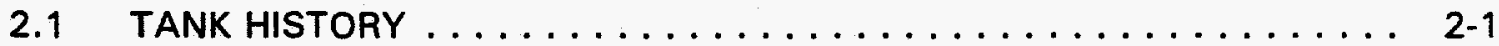

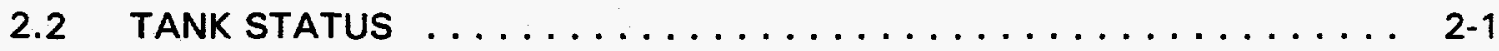

2.3 PROCESS KNOWLEDGE $\ldots \ldots \ldots \ldots \ldots \ldots \ldots \ldots \ldots \ldots . \ldots \ldots . \ldots .2-4$

2.4 HISTORICAL ESTIMATION OF THE CONTENTS OF TANK 241-AW-102 . 2 2-8

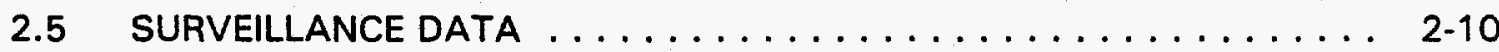

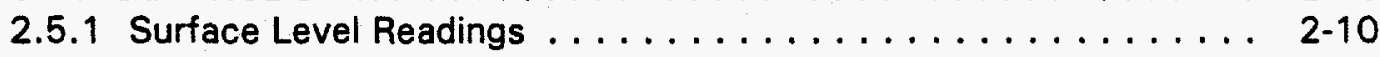

2.5.2 Internal Tank Temperatures ................. 2-11

3.0 PROGRAM ELEMENT SPECIFIC ANALYSES $\ldots \ldots \ldots \ldots \ldots \ldots \ldots \ldots \ldots$ 3-1

4.0 CONCLUSIONS AND RECOMMENDATIONS $\ldots \ldots \ldots \ldots \ldots \ldots \ldots \ldots \ldots$ 4-1

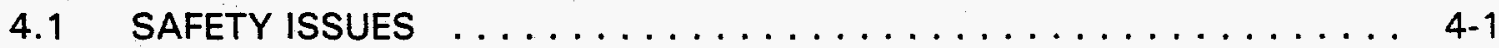

4.2 FURTHER CHARACTERIZATION NEEDS $\ldots \ldots \ldots \ldots \ldots \ldots \ldots \ldots$ 4-1

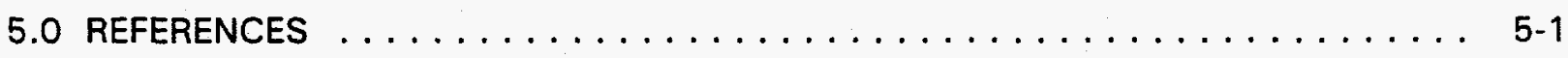

\section{LIST OF FIGURES}

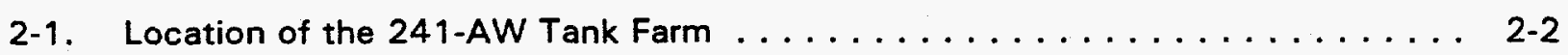

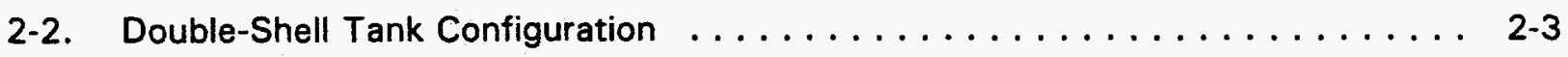

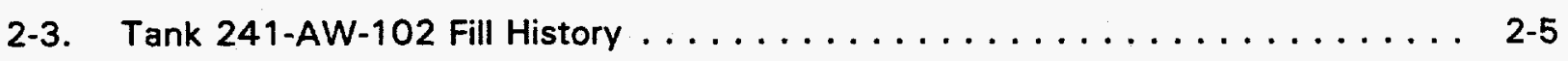

2-4. Tank 241-AW-102 Thermocouple Tree Raw Temperature Plot $\ldots \ldots \ldots$ 2-12 
WHC-SD-WM-ER-363 REV O

\section{LIST OF TABLES}

2-1. Tank 241-AW-102 Waste Received 1981-1994 . . . . . . . . . . . . . 2-6

2-2. Tank 241-AW-102 Waste Removed 1981-1994 . . . . . . . . . . . . . . 2-8

2-3. Analytical Data for Double-Shell Tank 241-AW-102 Prior to Evaporation . . . . 2-9

3-1. Applicability of Characterization Information to the Data Needs of the TWRS Program Elements ........................ 3-1

\section{LIST OF TERMS}

CASS Computer Automated Surveillance System

DN dilute non-complexed

DOE U.S. Department of Energy

DQO Data Quality Objective

EPA U. S. Environmental Protection Agency

FIC

PUREX Food Instrument Corporation

RCRA

TIC

TOC

TRU Plutonium-Uranium Extraction

Resource Conservation and Recovery Act total inorganic carbon total organic carbon

TWRS transuranic

WHC Tank Waste Remediation System Westinghouse Hanford Company 


\subsection{INTRODUCTION}

This Tank Characterization Report presents an overview of the waste transfer history of Tank 241-AW-102 and contains observations regarding waste characteristics which resulted from the 242-A Evaporator Campaign 94-1.

\subsection{PURPOSE}

The purpose of this report is to describe and characterize the waste in Double-Shell Tank 241-AW-102 (hereafter, Tank 241-AW-102) based on information obtained from various

sources. Specific objectives for the sampling and characterization of the waste in Tank 241AW-102 are to:

- Contribute toward the fulfillment of the Hanford Federal Facility Agreement and Consent Order (Tri-Party Agreement) Milestone M-44-05 concerning the characterization of Hanford Site high-level radioactive waste tanks (Ecology, EPA, and DOE, 1993).

- Provide tank waste characterization to the Tank Waste Remediation System (TWRS) Program Elements in accordance with the TWRS Tank Waste Analysis Plan (Bell, 1994).

\subsection{SCOPE}

This report deviates from the standard format for Tank Characterization Reports because of the special nature of the tank, as discussed in Section 1.3. Instead, a broad description of the tank and its historical background are presented. An estimation of the contents of Tank 241-AW-102 based on data presented in O'Rourke (1994) is also presented in this document. Finally, specific safety issues and program element needs are discussed.

\subsection{ASSUMPTIONS}

Tank 241-AW-102 is the designated feed tank for the 242-A Evaporator; consequently, its level and waste composition are constantly changing. Definitive characterization is not possible under dynamic conditions, and any waste inventory values generated quickly become obsolete. For these reasons, the sections of this Tank Characterization Report that describe the sampling event, the sample handling and analysis, and the statistical analysis are being omitted. The available analytical results and waste inventory are presented as historical data, in Chapter 2.0. General information concerning sampling events, sample handling, and analytical procedures can be obtained in the Tank Characterization Reference Guide (De Lorenzo et al., 1994), Sections 5.0 and 6.0. 
WHC-SD-WM-ER-363 REV 0

\subsection{HISTORICAL TANK INFORMATION}

The purpose of this section is to describe Tank 241-AW-102 based on historical tank information and surveillance data. This section is divided into five parts. A brief description and historical background of the tank comprise the first part, followed by recent tank status, a summary of the process sources that contribute to the tank waste, and a preliminary estimation of the tank waste constituents prior to the most recent evaporator campaign. The final part details the surveillance data taken on the tank.

\subsection{TANK HISTORY}

Tank 241-AW-102 was constructed and went into service in 1980 (Husa et al., 1993). The tank is one of six that comprise the AW Tank Farm located in the southeast side of the 200 East Area (Figure 2-1 details the Hanford Site's 200 East Area and the location of the AW Tank Farml. Tank 241-AW-102 is the designated waste feed tank for the 242-A Evaporator. Waste can be transferred to this tank from any other double-shell tank through the tank farm transfer and routing system (Loll, 1993).

Tank 241-AW-102 is a double-shell (tank-in-tank) design consisting of a heat-treated primary steel liner, inside a second steel liner. The tank has a design capacity for storing 4.39 million liters (1.16 million gallons) of waste. For most double-shell tanks, safety considerations require a maximum operating capacity of 4.31 million liters 11.14 million gallons); however, the maximum operating capacity for Tank 241-AW-102 is 3.96 million liters (1.05 million gallons) when the 242-A Evaporator is operating (Jonas, 1989). Instruments access Tank 241-AW-102 through risers and monitor the pressure, temperature, liquid level, sludge level, and other bulk tank characteristics (Bell, 1994). A detailed diagram of a double-shell tank is presented in Figure 2-2 (De Lorenzo et al., 1994). Active ventilation is used to keep the tank contents cool and to minimize the potential for release of airborne contaminants to the environment (Husa et al., 1993). Two airlift circulators agitate the waste within Tank 241-AW-102 to provide reasonably homogeneous evaporator feed.

Tank 241-AW-102 has been used to store waste from 19 other tanks and a number of additional sources, prior to processing in the evaporator (Koreski, 1994). A portion of processed waste from the evaporator campaigns was often returned to the tank for storage upon completion of each campaign (waste transfers are detailed in Section 2.3).

\subsection{TANK STATUS}

As of June 20, 1994, Tank 241-AW-102 contained a total waste volume of about 311,000 liters $(82,200$ gallons) (Rios, 1994). Prior to the most recent 242-A Evaporator campaign, Campaign 94-1, Tank 241-AW-102 contained supernatant liquid and a small amount, 3,790 liters (1,000 gallons), of sludge (Hanlon, 1994). Post-Campaign 94-1 information concerning the contributions of liquid and solid wastes to the inventory of Tank $241-A W-102$ is not available. 
Figure 2-1. Location of the 241-AW Tank Farm.

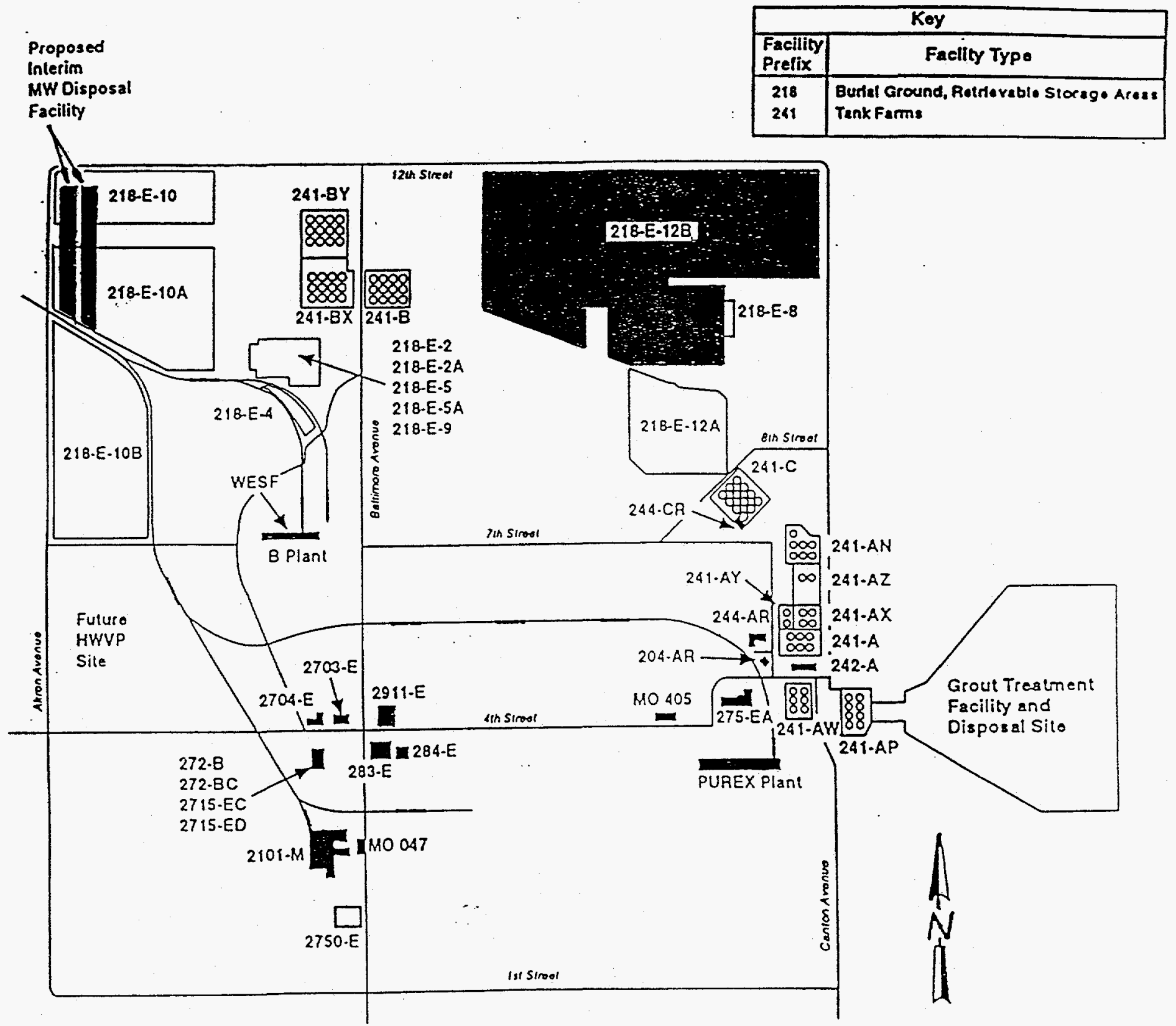


Figure 2-2. Double-Shell Tank Configuration.

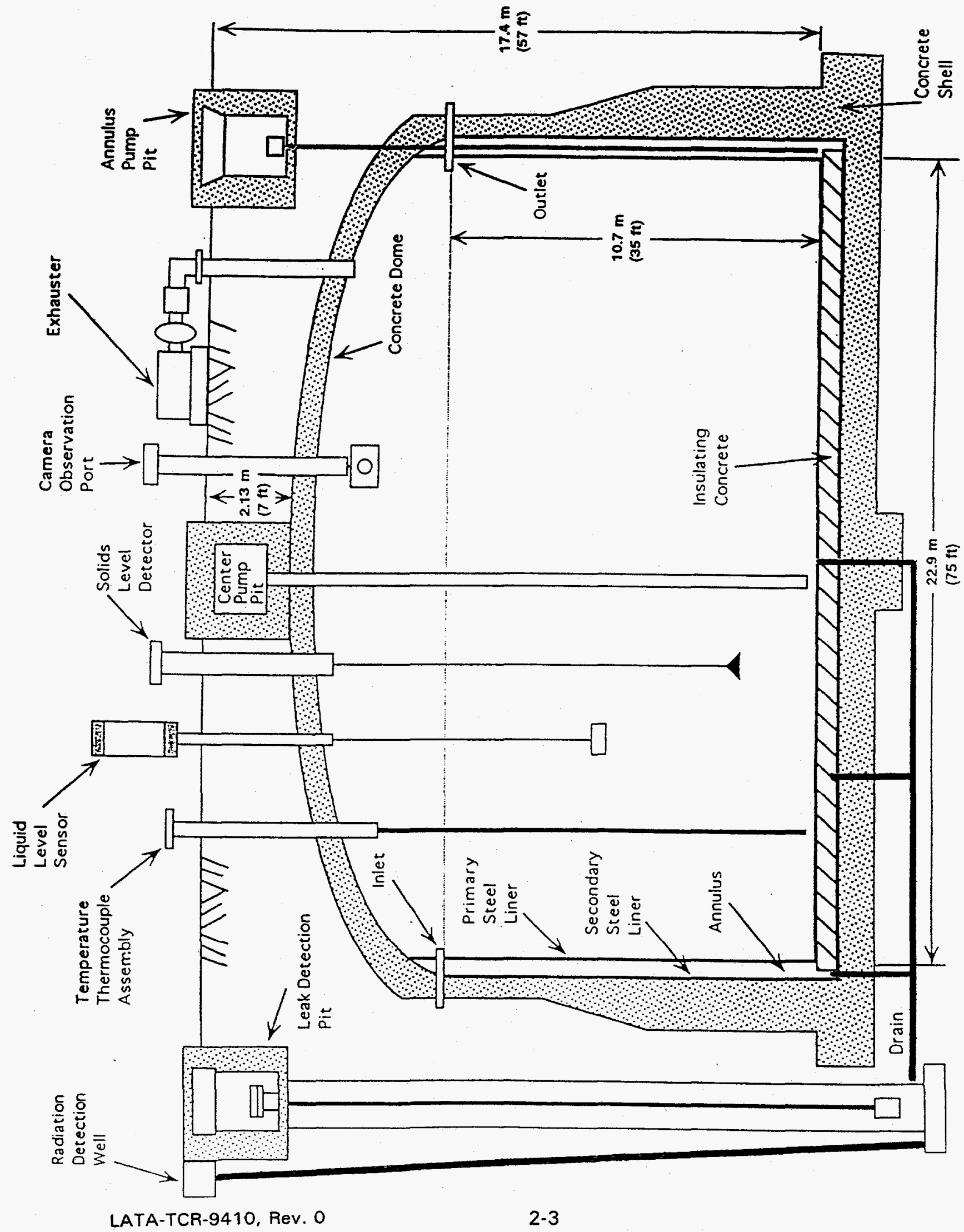


Tank 241-AW-102 remains in service. The "in service" designation allows the tank to continue receiving liquid in conjunction with production and/or waste processing. The tank integrity is classified as sound and it currently is a non-Watch List tank. There are no Unreviewed Safety Questions associated with Tank 241-AW-102 at this time.

Tank 241-AW-102 is equipped with both a manual tape and an automated liquid indicator device for surface level readings; both are operable. The waste occupied approximately $74 \mathrm{~cm}$ (29 inches) of this tank on June 20, 1994 (Rios, 1994). All tank monitoring instruments are in compliance with documentation (Hanlon, 1994). The last reported temperature was $33^{\circ} \mathrm{C}\left(91^{\circ} \mathrm{F}\right)$ on June $20,1994$.

At the conclusion of Campaign 94-1, the waste volume for Tank 241-AW-102 was expected to be minimal (O'Rourke, 1994). According to pre-campaign estimates, about 10.9 million liters (2.89 million gallons) of dilute non-complexed (DN) waste from Tanks 241-AW102, -AW-106, and -AP-103 were to be processed in the 242-A Evaporator with a projected waste volume reduction factor of $87 \%$. Prior to the latest campaign most of the waste in Tank 241-AW-102 consisted primarily of the partially concentrated product from Campaign 89-2.

\subsection{PROCESS KNOWLEDGE}

Tank 241-AW-102 has been emptied and refilled numerous times since 1981 in conjunction with the operation of the 242-A Evaporator. Figure 2-3 depicts the waste volume history of Tank 241-AW-102 from February 1981 to May 1994. When there are several transfers within one month, as was often the case, only the final tank volume at the end of that month was plotted. A detailed description of the transfers responsible for these fluctuations follows. These data are also summarized in Tables 2-1 and 2-2. All data were taken from the Waste Volume Projection Historical Database (Koreski, 1994) unless otherwise noted.

The Koreski data for Tank 241-AW-102 began in February 1981, showing a 148,000liter (39,000-gallon) addition of flush water. Additional transfers of dilute non-complexed waste from the PUREX Plant and Tank 241-SY-102, as well as flush water brought the waste volume in the tank to 3.71 million liters $(979,000$ gallons). This waste was fed to the $242-A$ Evaporator along with waste from Tanks 241-AW-101, -AZ-101, and -AY-102 as an evaporator campaign began in November 1981. Although the data show 8.52 million liters (2.25 million gallons) of waste in Tank 241-AW-102 in mid-November, this does not indicate that the tank capacity was exceeded. Since the precise dates of transfers are not now known, volume gains are recorded in the database as beginning on the first day of the month and losses on the 15th. In actual practice, however, the transfers were staggered to prevent overfilling. During November and December a cumulative total of 13.0 million liters 13.43 million gallons) of waste was fed to the Evaporator. The waste reduction factors were $52.6 \%$ in November and $57.4 \%$ in December. The concentrated waste was returned to both Tanks $241-A W-101$ and -102 . 
WHC-SD-WM-ER-363 REV O

Figure 2-3. Tank 241-AW-102 Fill History.

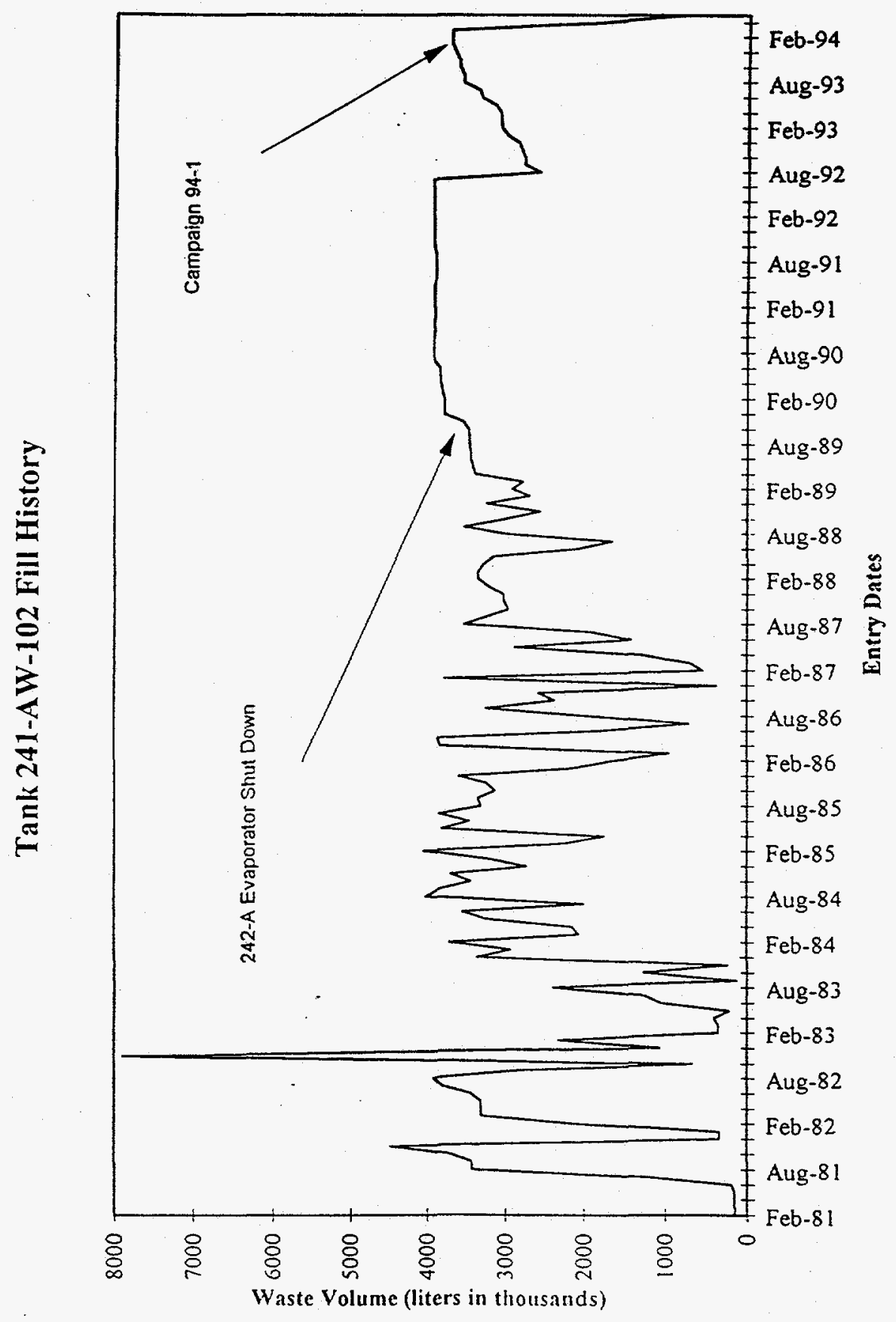


Table 2-1. Tank 241-AW-102 Waste Received 1981-1994.

\begin{tabular}{|c|c|c|c|c|}
\hline \multirow[b]{2}{*}{ Year: } & \multicolumn{2}{|c|}{ Waste Returned from Evaporator } & \multicolumn{2}{|c|}{ Other Gains } \\
\hline & $\begin{array}{l}\text { Numbes of } \\
\text { Transactions }\end{array}$ & $\begin{array}{l}\text { Volume, } 1000 \mathrm{~L} \\
\text { (1000 gations) }\end{array}$ & $\begin{array}{l}\text { Number of } \\
\text { Transactions }\end{array}$ & $\begin{array}{l}\text { Volume, } 1000 \mathrm{~L} \\
\text { (1000 gallons) }\end{array}$ \\
\hline 1981 & 2 & $\begin{array}{c}+526 \\
(+139)\end{array}$ & 15 & $\begin{array}{l}+12,780 \\
(+3,377)\end{array}$ \\
\hline 1982 & 4 & $\begin{array}{c}+6,048 \\
(+1,598)\end{array}$ & 22 & $\begin{array}{l}+26,530 \\
(+7,010)\end{array}$ \\
\hline 1983 & 5 & $\begin{array}{c}+5,257 \\
(+1,389)\end{array}$ & 22 & $\begin{array}{l}+18,800 \\
(+4,968)\end{array}$ \\
\hline 1984 & 14 & $\begin{array}{l}+35,860 \\
(+9,481)\end{array}$ & 33 & $\begin{array}{c}+70,500 \\
(+18,626)\end{array}$ \\
\hline 1985 & 11 & $\begin{array}{l}+31,010 \\
(+8,192)\end{array}$ & 43 & $\begin{array}{c}+62,260 \\
(+16,450)\end{array}$ \\
\hline 1986 & 12 & $\begin{array}{l}+19,780 \\
(+5,226)\end{array}$ & 44 & $\begin{array}{c}+59,530 \\
(+15,729\}\end{array}$ \\
\hline 1987 & 6 & $\begin{array}{l}+13,560 \\
(+3,582)\end{array}$ & 32 & $\begin{array}{l}+33,900 \\
(+8,957)\end{array}$ \\
\hline 1988 & 11 & $\begin{array}{l}+32,060 \\
(+8,469)\end{array}$ & 54 & $\begin{array}{c}+68,270 \\
(+18,037)\end{array}$ \\
\hline 1989 & 3 & $\begin{array}{c}+8,338 \\
(+2,203)\end{array}$ & 18 & $\begin{array}{l}+12,650 \\
(+3,341)\end{array}$ \\
\hline 1990 & $0^{*}$ & 0 & 5 & $\begin{array}{l}+140 \\
(+37)\end{array}$ \\
\hline 1991 & $0^{*}$ & 0 & 4 & $\begin{array}{c}+53 \\
(+14) \\
\end{array}$ \\
\hline 1992 & $0^{\circ}$ & 0 . & 7 & $\begin{array}{l}+288 \\
(+76)\end{array}$ \\
\hline 1993 & $0^{*}$ & 0 & 10 & $\begin{array}{c}+821 \\
(+217)\end{array}$ \\
\hline $1994^{\#}$ & 2 & $\begin{array}{c}+8,440 \\
(+2,230)\end{array}$ & 6 & $\begin{array}{l}+10,560 \\
(+2,791)\end{array}$ \\
\hline Total & 70 & $\begin{array}{l}+160,900 \\
(+42,509)\end{array}$ & 315 & $\begin{array}{l}+377,100 \\
(+99,630)\end{array}$ \\
\hline
\end{tabular}

"The 242-A Evaporator was shut down for modifications.

"Includes waste transactions through May 31, 1994.

Following the 1981 campaign, the contents of Tank 241-AW-102 changed continually with the operation of the 242-A Evaporator until the Evaporator was shut down in April 1989 for the resolution of safety issues and modifications. During this time, waste was transferred from several sources. They included: Tanks 241-AW-101, -103, -104, -105, -106, Tanks 241-AN-101, -102, -103, -105, Tanks 241-AP-101, -102, -103, -105, -106, Tanks 241-AY- 
101, -102, Tanks 241-AZ-101, -102, Tank 241-SY-102, miscellaneous PUREX Plant waste streams, decontamination waste from the $100 \mathrm{~N}$ Area, various waste streams from the 100 , 300 , and 400 areas, the Fuels Fabrication Facility, B Plant cesium processing, flush water, and unknown sources. Waste added to the tank from these sources are summarized in Table 2-1, under column "Other Gains". Similarly, in Table 2-2, the column labelled "Other Losses" includes waste removed from Tank 241-AW-102 and transferred to Tanks 241-AW-104, 105,-106, -AP-105, and -AN-106, as well as small amounts of unknown waste losses. At the conclusion of the 1989 campaign, Campaign 89-2, about 2.77 million liters 1731,000 gallons) of partially processed waste were left in the tank. Much of the waste processed during this campaign consisted of neutralized cladding removal waste and miscellaneous dilute wastes (Jonas, 1989).

Fill activity was minimal for Tank 241-AW-102 while modifications were being made to the 242-A Evaporator prior to its restart in 1994. Following Campaign 89-2, 1.02 million liters $(269,000$ gallons $)$ of water were added bringing the total waste volume of the tank to 3.79 million liters (1 million gallons) in December 1989. From 1990 to 1993, 1.37 million liters $(361,000$ gallons) were transferred to Tank 241 -AW-106 and 49,200 liters $(13,000$ gallons) were returned. A total of 136,000 liters $(36,000$ gallons) of flush water and 1.04 million liters $(275,000$ gallons) of evaporator pad flush were received. Also during this time, 64,300 liters (17,000 gallons) in unknown losses and 75,700 liters 120,000 gallons) in unknown gains were recorded. The most likely reasons for these losses and gains are evaporation and possible measurement inconsistencies, since $2.5 \mathrm{~cm}$ (1.0 inch) is equivalent to approximately 10,400 liters $(2,750$ gallons) of waste. The total waste volume for Tank 241-AW-102 at the end of 1993 was 3.66 million liters $(966,000$ gallons).

In January $1994,49,200$ liters $(13,000$ gallons) of pad flush were transferred into Tank 241-AW-102; later, in early April 1994, 3,790 liters (1,000 gallons) of unknown gain were received. During Evaporator Campaign 94-1, which began on April 15, 1994, a total of 3.40 million liters $(897,000$ gallons) of waste was initially moved from Tank 241-AW-106 to Tank 241-AW-102 in staged transfers, and 7.10 million liters (1.88 million gallons) were fed to the Evaporator. After a waste reduction of $67.3 \%, 4.78$ million liters 11.26 million gallons) were returned to Tank 241-AW-102. In April and May of 1994, a cycling of 2.94 million liters (777,000 gallons) between Tanks 241-AW-106 and 241-AW-102 occurred with no net volume change in either tank. Then, 4.17 million liters ( 1.10 million gallons) from Tank 241-AP-103 were mixed with this processed waste and 8.96 million liters 12.37 million gallons) were fed to the Evaporator. Of the 3.66 million liters $(967,000$ gallons) returned to Tank 241-AW-102 following processing, 2.85 million liters (753,000 gallons) were transferred to Tank 241-AW-106, leaving 810,000 liters $(214,000$ gallons) of waste in Tank 241-AW102 on May 27. An unknown gain of 3,790 liters (1,000 gallons) brought the volume of Tank 241-AW-102 to 814,000 liters (215,000 gallons) by the end of May 1994. Beginning on June 3, waste was moved back into Tank 241-AW-102 from Tank 241-AW-106 for further evaporation. These transfers into Tank 241-AW-102 continued until the waste volume reached 2.61 million liters $(690,000$ gallons) on June 5 . Transfers to the Evaporator commenced on June 7 and continued through June 12, leaving a volume of 174,000 liters (46,000 gallons) in Tank 241-AW-102. Since the completion of the evaporator campaign, 137,000 liters $(36,200$ gallons) of flush water from the evaporator have been added, leaving a final volume of 311,000 liters $(82,200$ gallons) in the tank as of June 20 . 
Table 2-2. Tank 241-AW-102 Waste Removed 1981-1994.

\begin{tabular}{|c|c|c|c|c|}
\hline \multirow[b]{2}{*}{ Year } & \multicolumn{2}{|c|}{ Waste Transferred to Evaporator } & \multicolumn{2}{|c|}{ Other Losses } \\
\hline & $\begin{array}{l}\text { Number of } \\
\text { Transactions }\end{array}$ & $\begin{array}{l}\text { Volume, } 1000 \mathrm{~L} \\
\text { (1000 gallons) }\end{array}$ & $\begin{array}{l}\text { Number of } \\
\text { Transactions }\end{array}$ & $\begin{array}{l}\text { Volume, } 1000 \mathrm{~L} \\
\text { (1000 gallons) }\end{array}$ \\
\hline 1981 & 4 & $\begin{array}{c}-12,980 \\
(-3,430)\end{array}$ & 0 & 0 \\
\hline 1982 & 9 & $\begin{array}{c}-31,850 \\
(-8,415)\end{array}$ & 0 & 0 \\
\hline 1983 & 10 & $\begin{array}{c}-19,170 \\
(-5,066)\end{array}$ & 2 & $\begin{array}{r}-2,589 \\
(-684)\end{array}$ \\
\hline 1984 & 31 & $\begin{array}{c}-107,000 \\
(-28,273) \\
\end{array}$ & 1 & $\begin{array}{c}-4 \\
(-1) \\
\end{array}$ \\
\hline 1985 & 24 & $\begin{array}{c}-86,250 \\
(-22,786)\end{array}$ & 2 & $\begin{array}{c}-6,151 \\
(-1,625)\end{array}$ \\
\hline 1986 & 26 & $\begin{array}{c}-82,480 \\
(-21,792)\end{array}$ & 1 & $\begin{array}{l}-64 \\
(-17)\end{array}$ \\
\hline 1987 & 12 & $\begin{array}{c}-42,470 \\
(-11,221)\end{array}$ & 1 & $\begin{array}{r}-2,320 \\
(-613)\end{array}$ \\
\hline 1988 & 22 & $\begin{array}{c}-97,900 \\
(-25,866)\end{array}$ & 2 & $\begin{array}{r}-2,210 \\
(-584)\end{array}$ \\
\hline 1989 & 9 & $\begin{array}{c}-20,440 \\
(-5,401)\end{array}$ & 0 & 0 \\
\hline 1990 & $0^{*}$ & 0 & 2 & $\begin{array}{l}-15 \\
(-4)\end{array}$ \\
\hline 1991 & $0^{*}$ & 0 & 3 & $\begin{array}{l}-45 \\
(-12)\end{array}$ \\
\hline 1992 & $0^{*}$ & 0 & 2 & $\begin{array}{r}-1,370 \\
(-362)\end{array}$ \\
\hline 1993 & $0^{*}$ & 0 & 0 & 0 \\
\hline $1994^{\#}$ & 2 & $\begin{array}{c}-16,060 \\
(-4,242)\end{array}$ & 2 & $\begin{array}{r}-5,791 \\
(-1,530)\end{array}$ \\
\hline Total & 149 & $\begin{array}{c}-516,600 \\
(-136,492)\end{array}$ & 18 & $\begin{array}{c}-20,560 \\
(-5,432)\end{array}$ \\
\hline
\end{tabular}

The 242-A Evaporator was shut down for modifications.

\#Includes waste transactions through May 31, 1994.

\subsection{HISTORICAL ESTIMATION OF THE CONTENTS OF TANK 241-AW-102}

A preliminary estimation of the contents of Tank $241-A W-102$ is complicated by the use of this waste tank as the dedicated feed tank for the 242-A Evaporator. Its contents continually change with each evaporator campaign. However, the analysis of liquid waste samples taken from Tank 241-AW-102 in late 1993 provides an estimation of the 
radionuclide, organic, and inorganic constituents of the liquid waste in the tank prior to the most recent evaporator campaign, Campaign 94-1 (O'Rourke, 1994). A total of eight supernatant samples were taken from one riser of Tank 241-AW-102. The airlift circulators in the tank were operated for a minimum of 24 hours prior to the sampling event. Table 2-3 presents analytical results of selected radionuclides, one organic analyte (a mean of four samples), and the estimated concentrations of selected inorganic analytes.

The radionuclide results were obtained from composite samples. The concentrations of the inorganic constituents were derived by taking into account the original sample data, subsequent dilution with water, and transfers to Tank 241-AW-106.

Concentrations measured analytically are recorded as Tank Characterization Result. These concentrations, obtained from supernate samples, were converted into Total Tank Inventory values using the current total waste volume of $311,000 \mathrm{~L}$.

Table 2-3. Analytical Data for Double-Shell Tank 241-AW-102 Prior to Evaporation.

\begin{tabular}{|c|c|c|}
\hline Analyte & Tank Characterization Result & Total Tank Inventory \\
\hline Metals & $(\mu \mathrm{g} / \mathrm{L})$ & (kg) \\
\hline Aluminum (Al) & $3.46 \mathrm{E}+05$ & 108 \\
\hline Sodium (Na) & $1.19 \mathrm{E}+07$ & 3,700 \\
\hline \multicolumn{3}{|l|}{ lons } \\
\hline Ammonium $\left(\mathrm{NH}_{4}{ }^{+}\right)$ & $127(\mathrm{ppm})$ & 39.5 \\
\hline Fluoride $\left(\mathrm{F}^{-}\right)$ & $2.85 E+06$ & 886 \\
\hline Hydroxide $\left(\mathrm{OH}^{\prime}\right)$ & $2.04 \mathrm{E}+06$ & 634 \\
\hline Nitrate $\left(\mathrm{NO}_{3}{ }^{-}\right)$ & $1.02 \mathrm{E}+07$ & 3,170 \\
\hline Nitrite $\left(\mathrm{NO}_{2}{ }^{-}\right)$ & $1.82 E+06$ & 566 \\
\hline Phosphate $\left(\mathrm{PO}_{4}{ }^{3-}\right)$ & $1.24 E+05$ & 38.6 \\
\hline Sulfate $\left(\mathrm{SO}_{4}{ }^{2-}\right)$ & $1.74 E+06$ & 541 \\
\hline \multicolumn{3}{|l|}{ Other } \\
\hline TIC & $5.80 E+05$ & 180 \\
\hline TOC & $3.39 E+05$ & 105 \\
\hline Acetone & 436 & 0.136 \\
\hline Radionuclides & $(\mu \mathrm{Ci} / \mathrm{mL})$ & (Ci) \\
\hline${ }^{3} \mathrm{H}$ & 0.00572 & 1.78 \\
\hline${ }^{14} \mathrm{C}$ & $5.09 E-09$ & $1.58 E-06$ \\
\hline${ }^{60} \mathrm{Co}$ & $<0.00564$ & $<1.75$ \\
\hline${ }^{79} \mathrm{Se}$ & 1.51E-05 & 0.00470 \\
\hline${ }^{90} \mathrm{Sr}$ & 0.0452 & 14.1 \\
\hline${ }^{94} \mathrm{Nb}$ & $<0.0054$ & $<1.7$ \\
\hline${ }^{99} \mathrm{Tc}$ & 0.00438 & 1.36 \\
\hline${ }^{106} \mathrm{Ru}$ & $<0.398$ & $<124$ \\
\hline
\end{tabular}


Table 2-3. Analytical Data for Double-Shell Tank 241-AW-102 Prior to Evaporation.

\begin{tabular}{|r|c|c|}
\hline Analyte & Tank Characterization Result & Total Tank Inventory \\
\hline Radionuclides (continued) & (wCi/mL) & (Ci) \\
\hline${ }^{113} \mathrm{Sn}$ & $<0.0283$ & $<8.80$ \\
\hline${ }^{129} \mathrm{l}$ & $<3.46 \mathrm{E}-08$ & $<1.08 \mathrm{E}-05$ \\
\hline${ }^{134} \mathrm{Cs}$ & 0.175 & 54.4 \\
\hline${ }^{137} \mathrm{Cs}$ & 15.3 & 4,760 \\
\hline${ }^{144} \mathrm{Ce}$ & $<0.155$ & $<48.2$ \\
\hline${ }^{154} \mathrm{Eu}$ & $<0.0215$ & $<6.69$ \\
\hline${ }^{155} \mathrm{Eu}$ & $<0.0423$ & $<13.2$ \\
\hline${ }^{226} \mathrm{Ra}$ & $<0.337$ & $<105$ \\
\hline${ }^{239 / 240} \mathrm{Pu}$ & $3.61 \mathrm{E}-04$ & 0.112 \\
\hline${ }^{241} \mathrm{Am}$ & $<1.72 \mathrm{E}-04$ & $<0.0535$ \\
\hline $\mathrm{U}_{\mathrm{Gross}}$ & $0.0175(\mathrm{~g} / \mathrm{L})$ & $5.44(\mathrm{~kg})$ \\
\hline & & \\
\hline
\end{tabular}

Among the cations for which data are available, aluminum is abundant and is almost completely water-insoluble. The majority of aluminum compounds present in the sludge are most likely $\mathrm{Al}(\mathrm{OH})_{3}$. Other possible aluminum precipitates are aluminum silicate $\left(\mathrm{Al}_{2} \mathrm{O}_{3} \cdot \mathrm{SiO}_{2}\right)$ and aluminum orthophosphate $\left(\mathrm{AIPO}_{4}\right)$. Sodium, on the other hand, is not expected to precipitate but rather to remain in the supernatant liquid. The anions listed in Table 2-3 are expected to be present in both the sludge and the supernatant liquid.

The inventory estimates presented in Table 2-3 are not necessarily representative of current tank conditions and are shown for information purposes only. Tank 241-AW-102 remains in active service and is involved in the various ongoing waste management operations at the Hanford Site. Real-time tank inventories can be obtained from Tank Farm Operations. The Tank Characterization Reports for tanks still receiving waste will be revised as new information becomes available, on a quarterly basis, if necessary. However, due to the inherent delay in the revision and issuance of the document, the most current and authoritative data will be with Tank Farm Operations personnel.

\subsection{SURVEILLANCE DATA}

\subsubsection{Surface Level Readings}

To determine the surface level of the waste, Tank 241-AW-102 is equipped with both an automatic gauge manufactured by the Food Instrument Corporation (FIC) and a manual tape. The manual tape readings are used when the FIC indicator is out of service. Both devices are currently operable. The most recent FIC liquid level measurement available was $75.9 \mathrm{~cm}$ (29.9 inches) on June 20,1994 . The manual tape reading for the same date was $73.7 \mathrm{~cm}$ (29.0 inches) (Rios, 1994), a discrepancy amounting to 9,380 liters (2,480 gallons). 
The FIC indicator uses a conductivity electrode which is lowered by machine until electrical contact is established with the waste surface; it can be monitored either automatically or manually (Husa et al., 1993). When monitored automatically, the FIC gauge is electrically connected to a computer for data transmission, analysis, and reporting via the Computer Automated Surveillance System (CASS). The manual tape also uses a conductivity probe but must be lowered by hand crank.

\subsubsection{Internal Tank Temperatures}

Each double-shelled tank is equipped with approximately 100 thermocouples. A probe with 18 thermocouples assembled in a pipe, called a thermocouple tree, is inserted into a waste tank and used to monitor the waste temperatures at various levels in the primary containment tank, usually every two feet. Except for three time periods when thermocouple equipment was apparently out of service, the temperature readings for Tank 241-AW-102 have been automatically recorded since the beginning of the third quarter 1989 by CASS. The maximum temperature readings from thermocouple tree one, which enters the tank at riser 4A (refer to the riser diagram in the executive summary), are plotted in Figure 2-4. This graph, taken from Rios (1994), covers most of the time period between Evaporator Campaigns 89-2 and 94-1, the only extended period of relative inactivity for the tank since 1981. The contents of Tank 241-AW-102 have since changed. The last available temperature reading for Tank $241-\mathrm{AW}-102$ was $33^{\circ} \mathrm{C}\left(91^{\circ} \mathrm{F}\right)$ on June $20,1994$.

Figure 2-4 shows that the temperature of the tank contents exhibited seasonal fluctuations. This is particularly evident from the 1992 to 1993 data. Seasonal fluctuations are expected since the soil between the surface level and approximately $3 \mathrm{~m}(10 \mathrm{ft})$ below surface level creates a zone that is thermally transient, thus displaying diurnal and seasonal variations in temperature (Freeze and Cherry, 1979). Usually the soil below this thermally transient zone attenuates the effects of changing ambient air temperature. The bottom of the tank is $18 \mathrm{~m}$ (60 ft) below the surface level, but, unlike a solid mass of soil, the effects of changing air temperature are felt because the tank is a more efficient heat conductor. The tank's metal and concrete container filled with liquid, surrounded by actively ventilated annular space and connected to the surface by risers and drywell openings, will transfer heat to and from the surface readily. Furthermore, the active ventilation system forces heat transfer between the tank contents and the ambient air. Seasonal variations may have caused the temperatures of the waste in Tank 241-AW-102 to fluctuate between readings in the 30's to mid 10's degrees centigrade 180's to lower 60's degrees Fahrenheit.) Temperature fluctuations in Tank 241-AW-102 may also be due to heat loss after evaporation processing and/or as a result of changing waste volume. Since the values plotted in Figure 2-4 are always the highest of all temperatures recorded on the thermocouple tree on a given day, and therefore not necessarily taken at the same point on the thermocouple tree, they could represent the sludge temperature, the supernatant temperature, or even the temperature of the air space above the waste.

Overall, the average temperature inside the tank appears to have decreased slightly during the period as flush water was added prior to Campaign 94-1. A number of anomalous high readings appear in Figure $2-4$. One of them, $33^{\circ} \mathrm{C}\left(92^{\circ} \mathrm{F}\right)$ in the second quarter of 1990 , indicates a temperature jump of nearly $16^{\circ} \mathrm{C}\left(28^{\circ} \mathrm{F}\right)$ and subsequent drop of about $11^{\circ} \mathrm{C}$ $\left(19^{\circ} \mathrm{F}\right)$, all within a matter of weeks. Since this and other anomalous readings were taken during a time of little fill activity, the most likely reason for them appears to be either equipment malfunctions or perhaps incorrect recording or transmission of the readings. 
WHC-SD-WM-ER-363 REV 0

Figure 2-4. Tank 241-AW-102 Thermocouple Tree Raw Temperature Plot (Rios, 1994).

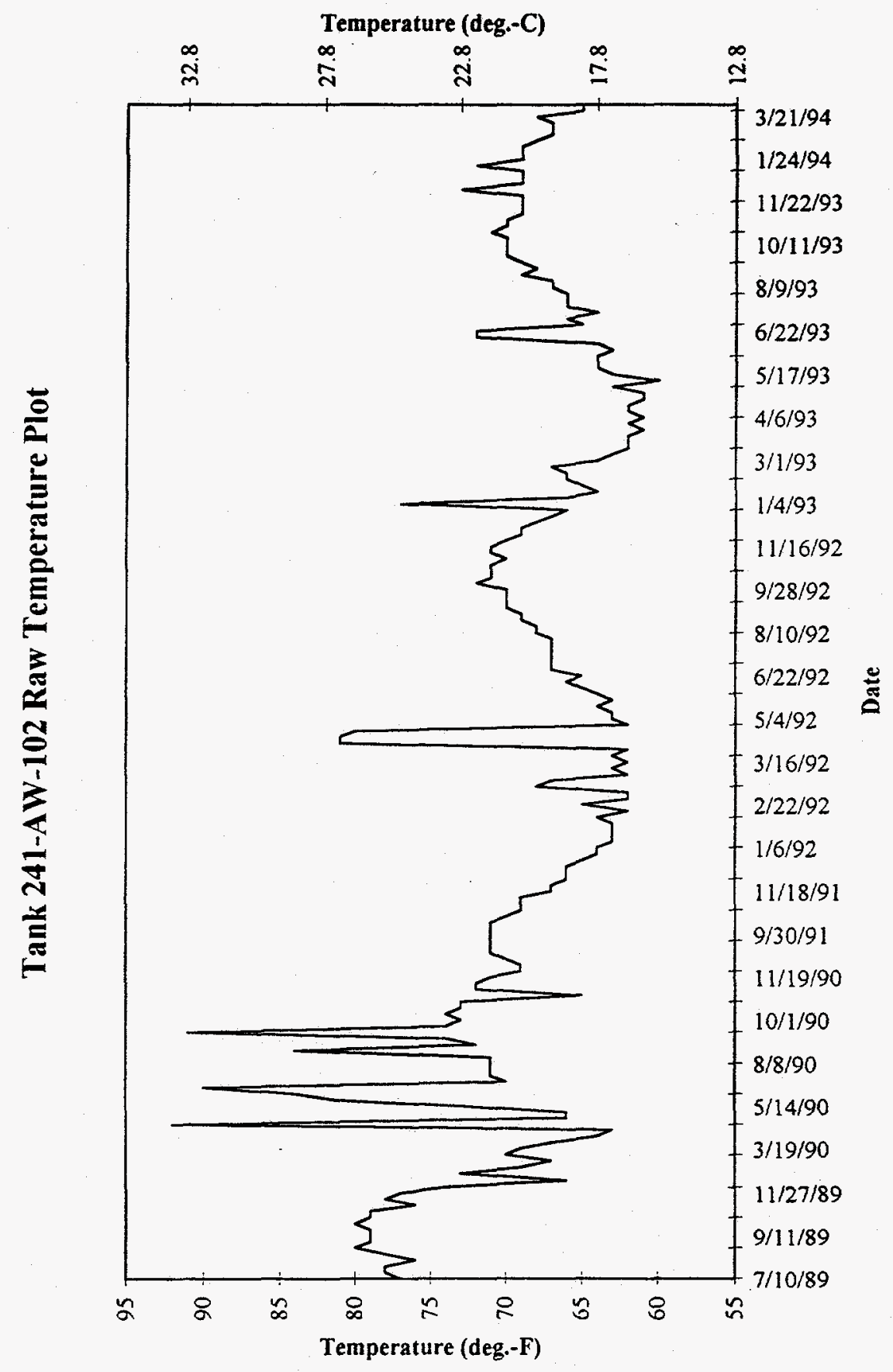




\subsection{PROGRAM ELEMENT SPECIFIC ANALYSES}

The sampling and analysis of Hanford Site waste tanks are driven by the need to satisfy the characterization requirements of the various Tank Waste Remediation System (TWRS) program elements. These characterization needs are implemented and documented through the Data Quality Objective (DOO) process, and expressed in a series of program specific DQO documents. The data needs are summarized in the TWRS Tank Waste Analysis Plan (Bell, 1994).

This Tank Characterization Report is the final step in the characterization of Tank 241AW-102. According to the process and issue based data requirements, the inventory estimates and waste properties contained in this report can be applied to the data requirements of the various program elements. Contained in Table 3-1 is a summary of which program data needs are fulfilled through this characterization of the waste in Tank 241-AW102 , based on a review of the stated sampling and analysis requirements. In the future, the applicability of Tank Characterization Report results to each TWRS program element will be documented in tank specific Tank Characterization Plans, prior to the tank sampling.

Table 3-1. Applicability of Characterization Information to the Data Needs of the TWRS Program Elements.

\begin{tabular}{|l|c|}
\hline \multicolumn{1}{|c|}{ Data Quality Objective } & $\begin{array}{c}\text { Applicability to Characterization } \\
\text { of Tank 241-AW-102 }\end{array}$ \\
\hline Tank Safety Screening & applies' \\
\hline Ferrocyanide Safety Issue & does not apply \\
\hline Flammable Gas Tanks Crust Burn Issue & does not apply \\
\hline Generic Tank Vapor Issue Resolution & not addressed \\
\hline Flammable Gas Tank & not completed \\
\hline Waste Compatibility & applies \\
\hline Organic Fuel Rich Tank & does not apply \\
\hline Rotary Core Vapor Sampling & does not apply \\
\hline Evaporator Operations & not completed \\
\hline Process Control & not completed \\
\hline Waste Tank Retrieval & not completed \\
\hline Waste Tank Pretreatment & not completed \\
\hline High-Level Waste Immobilization & not completed \\
\hline Low-Level Waste Immobilization & not completed \\
\hline Solid, Low-Level Waste Disposal & not completed \\
\hline RCRA Part B Permit Application & not completed \\
\hline
\end{tabular}


Table 3-1. Applicability of Characterization Information to the Data Needs of the TWRS Program Elements.

\begin{tabular}{|l|c|}
\hline \multicolumn{1}{|c|}{ Data Quality Objective } & $\begin{array}{c}\text { Applicability to Characterization } \\
\text { of Tank 241-AW-102 }\end{array}$ \\
\hline Tank C-106 High-Heat Safety Issue & does not apply \\
\hline Organic Layer Sampling of Tank C-103 & does not apply \\
\hline Tank C-103 Vapor and Gas Sampling & does not apply \\
\hline
\end{tabular}

Objective (Babad 1994) calls for both vertical waste samples and vapor space sample. The sampling and analysis of Tank 241-AW-102 support full characterization of the waste in the tank; vapor space sampling or characterization was not conducted as part of this activity.

applies - The data needs expressed in this Data Quality Objectives document are fulfilled through this characterization report.

does not apply - The data needs expressed in this Data Quality Objectives document do not apply to the waste in Tank 241-AW-102.

not addressed - The data needs expressed in this Data Quality Objectives document were not addressed by this characterization report.

not complete - At the date of preparation of this report, this Data Quality Objectives document has not yet been completed.

There are two DQOs that apply to Tank 241-AW-102. The DQO for Tank Safety Screening has been developed for rapid classification of the 177 single-shell tanks and doubleshell tanks containing high-level radioactive waste. Specific sampling and analytical requirements for this safety screening are contained in the Tank Safety Screening Data Quality Objective (Babad, 1994). The objective of the safety screening is to support tank safety issue resolution and to classify the waste tanks into specific safety categories for issues concerning ferrocyanide content, flammable gases, organic safety concerns, and criticality. Concerns related to high-heat and vapor content are not subject to this screening activity. Key parameters to be measured during screening are: energetics, $\%$ water, total alpha concentration, and lower flammability limit of the gases in the dome space.

As the feeder tank for the 242-A Evaporator, the role of Tank 241-AW-102 is to receive waste en route to the evaporator from other double-shell tanks. The waste is then transferred into the evaporator, where the volume of the waste is reduced. The waste is eventually transferred back to double-shell tanks for long-term storage. Before any waste is accepted by the evaporator, the waste is sampled and analyzed. Samples are used to determine if a particular double-shell tank contains waste that is suitable for 242-A Evaporator processing. The results are compared with the process operating limits, and a determination is made and documented in the campaign plan for each batch of waste processed. This process is followed in the Process Control Plan for 242-A Evaporator Campaign 94-1 (O'Rourke, 1994). If the tank is determined to be unacceptable for processing, it will be segregated from other waste tanks which are potential feed tanks for processing. All waste designated for processing in the 242-A Evaporator must meet double-shell tank boundary 
condition limits. It can thus be concluded with confidence that the waste in Tank 241-AW102 is within these set safety limits. Due to the decrease in water volume associated with the evaporator process, there are precipitates formed in the concentrated slurry routed to the evaporator receiver tank, Tank 241-AW-106. When waste necessitating further concentration is cycled back to Tank 241-AW-102 from Tank 241-AW-106, some of these suspended solids are included in the transfer. This recycling has formed a very thin, about $3 \mathrm{~cm}$ (1 inch), layer of solids on the bottom of the tank. There is, however, a potential for these precipitates to redissolve as dilute feed is processed through Tank 241-AW-102 for future evaporator campaigns.

Data Quality Objectives for the Waste Compatibility Program have been created to identify safety and operations decision elements relevant to waste transfers both within and external to the Hanford Site double-shell tank system. These DOOs also describe quantitative decision limits. The primary decision for waste compatibility is whether or not to allow a waste transfer. Four safety-related decision elements have been identified: criticality, flammable gas accumulation, energetics, and corrosivity. Operations-related elements include separation of transuranic (TRU) waste from non-TRU waste, limits on heat generation, and segregation of complexant waste (high organic content). When a quantified decision limit has been exceeded, the waste requires further attention before the transfer can proceed. These DOOs are outlined in the Data Quality Objectives for the Waste Compatibility Program (Carothers, 1994). As mentioned above, these decision criteria are considered in operation of the 242-A Evaporator. Since all waste transfers must meet these criteria, and since the waste present in Tank 241-AW-102 results from transfers from other double-shell tanks, it is reasonable to conclude that the waste in Tank 241-AW-102 meets these criteria. 


\subsection{CONCLUSIONS AND RECOMMENDATIONS}

\subsection{SAFETY ISSUES}

According to the Process Control Plan for 242-A Evaporator Campaign 94-1 (O'Rourke, 1994), the predicted inventory of fissionable radionuclides, organic or exothermic waste constituents, and flammable gas producing compounds indicates that no credible potential exists for loss of tank integrity or release of radioactivity due to tank farm processes. Tank 241-AW-102 is considered sound and non-leaking (Hanlon 1994l, and examination of the waste volume history supports this conclusion (Koreski, 1994). Thermocouple data indicate no self heating problem exists. Therefore, there is no credible risk of self-boiling or excessive heating of the current tank contents.

\subsection{FURTHER CHARACTERIZATION NEEDS}

Since Tank 241-AW-102 is the feed tank for the 242-A Evaporator, its contents continually change during evaporator campaigns. A complete characterization of the waste would require a sampling event to be conducted under static conditions with respect to tank farm operations. It may be useful to determine the composition of any precipitated solids and organic complexants in the tank upon completion of the evaporator campaign. 


\subsection{REFERENCES}

Babad, H., 1994. Tank Safety Screening Data Quality Objective, WHC-SD-WM-004, Westinghouse Hanford Company, Richland, WA.

Bell, K.E., 1994. Tank Waste Remediation System Tank Waste Analysis Plan, WHC-SD-WMPLN-077, Rev. 0, Westinghouse Hanford Company, Richland, WA.

Carothers, K.G., 1994. Data Quality Objectives for the Waste Compatibility Program, WHCSD-WM-DQ0-001, Rev. 0, Westinghouse Hanford Company, Richland, WA.

De Lorenzo, D.S., J.H. Rutherford, D.J. Smith, D.B. Hiller, and K.W. Johnson, 1994. Tank Characterization Reference Guide, WHC-SD-WM-TI-648, (LATA-TCR-9491), Los Alamos Technical Associates, Kennewick, WA.

Ecology, 1991. "Dangerous Waste Regulations," WAC 173-303, Washington State Department of Ecology, Olympia, WA.

Ecology, EPA, and DOE, 1993. Hanford Federal Facility Agreement and Consent Order, Washington State Department of Ecology, U.S. Environmental Protection Agency, and U.S. Department of Energy, Olympia, WA.

EPA, 1990. "Identification and Listing of Hazardous Wastes", 40 CFR Part 261.

Freeze, R.A., and J.A. Cherry, 1979. "Groundwater and Thermal Processes," Groundwater, Prentice-Hall, Inc., Englewood Cliffs, N.J.

Hanlon, B.L., 1994. Tank Farm Surveillance and Waste Status Summary Report for January 1994, WHC-EP-0182-70, Westinghouse Hanford Company, Richland, WA.

Husa, E.I., R.E. Raymond, R.K. Welty, S.M. Griffith, B.M. Hanlon, R.R. Rios, and N.J. Vermeulen, 1993. Hanford Site Waste Storage Tank Information Notebook, WHC-EP-0625, Westinghouse Hanford Company, Richland, WA.

Jonas, A.L., 1989. 242-A Evaporator/Crystallizer Fiscal Year 1989 Campaign Run 89-2 Post Run Document, WHC-SD-WM-PM-038, Rev. 0, Westinghouse Hanford Company, Richland, WA.

Koreski, G.M., 1994. Waste Volume Projection Historical Database, Westinghouse Hanford Company, Richland, WA.

Loll, C.M., 1993. 242-A Evaporator Waste Analysis Plan, WHC-SD-WM-EV-060, Rev. 2, Westinghouse Hanford Company, Richland, WA.

O'Rourke, J.F., 1994. Process Control Plan for 242-A Evaporator Campaign 94-1, WHC-SDWM-PCP-008, Rev. 1, Westinghouse Hanford Company, Richland, WA.

Rios, R.R., 1994. Computer Automated Surveillance System, Westinghouse Hanford Company, Richland, WA. 